\title{
Discerning the role of faith communities in responding to urban youth marginalisation
}

\begin{abstract}
Author:
Reginald W. Nel ${ }^{1}$

Affiliation:

${ }^{1}$ Department of Christian Spirituality, Church History and Missiology, University of South Africa, South Africa

\section{Note:}

This article forms part of the special collection on 'Doing urban public theology in South Africa: Visions, approaches, themes and practices towards a new agenda' in HTS Teologiese Studies/Theological Studies Volume 70, Issue 3, 2014. The collection is the result of the project 'Urban Public Theology', which was initiated by the Institute for Urban Ministry but later expanded to include several academic departments and institutes at the University of Pretoria (UP) and University of South Africa (UNISA). The leading centres in this regard were the Centre for Contextual Ministry (UP) and the Research Institute for Theology and Religion (UNISA).
\end{abstract}

\section{Correspondence to:}

Reginald Nel

Email:

rwnel@unisa.ac.za

Postal address:

PO Box 329, UNISA 0003,

Pretoria, South Africa

Dates:

Received: 28 May 2014

Accepted: 08 July 2014

Published: 20 Nov. 2014

Read online:
Urban youth marginalisation became a key consideration in scholarly and policy literature in the 1990s. This entailed a shift from an emphasis on youth in relation to activism in the struggle to overcome colonial racism - popularly known as 'the struggle against apartheid' - to an emphasis on youth as the object of social inquiry and social welfare programmes. Irrespective of how we evaluate this shift, the question in this article is how urban faith communities and youth ministry research are to respond to the agency of youth as dialogue partners - with a focus on social cohesion. This article explores this shift in scholarship on urban youth movements, especially for the period since 1994. It draws from the perspectives of my recent doctoral studies (Nel 2013) in constructing a creative dialogue with youth movements. The ultimate aim of this article is to provide a grounded basis for constructing a methodology for a postcolonial urban theology. In addition, it aims to inform the ongoing Youth at the Margins (YOMA) comparative study on the contribution of faith-based organisations to social cohesion in South Africa and Nordic Europe, with the Riverlea community, in Johannesburg, as one of the case studies.

\section{Introduction}

In 2009, a few months before the kick-off of the 2010 FIFA Soccer World Cup, young people from Riverlea 1, a residential area to the south of Johannesburg, threatened to disrupt the soccer spectacle, even though, ironically, soccer is the favourite sport of these residents, in particular the youth. One resident threatened: 'If you don't build us houses, there will be no 2010 Fifa World Cup match played at the Soccer City Stadium!' (Tau 2009). Why would young people take to the streets to protest against soccer?

Youth are often portrayed as being at the forefront of recognising and responding to the ongoing transformations in the world. Enthusiastically, they will challenge and transgress existing boundaries while they leave old ones behind; they reimagine and embrace different spaces where there are some indications that the new or different is being understood, or at least affirmed and engaged. These hopeful assertions about the activism of younger people, as demonstrated by those from Riverlea, are echoed by leaders and activists within popular youth movements (Leffel 2007:45, 79-109; Naidoo 2009:153-168) as well as in the literature on youth research (Bray et al. 2010:28-29; Klouwerberg \& Butter 2011:56, 58; Naidoo 2009:153-154; Philipps 2014:2-3; Van Dijk et al. 2011:2-5; Wyn \& White 1997). This interest shifted in the South African context from what I would broadly call an emphasis on youth in relation to the struggle to overcome colonial racism, popularly known as 'the struggle against apartheid', to an emphasis on youth as the object of social inquiry and social welfare programmes, in the struggle against marginalisation.

\section{Youth in the struggle against apartheid}

In the South African context this activism in the struggle against colonialism racism, has been one of the prominent features of our recent history (Hlongwane, Ndlovu \& Mutloatse 2006; Hyslop 1990:79-87; Soudien 2007:5; Straker 1992). Prishani Naidoo, a former student activist in this context, states boldly that 'the struggles of black youth against apartheid are etched in the collective memory of South Africans in the world ...' (Naidoo 2009:155). These scholars argue that apart from the impact that social transformation has had on young people's lives (positive or negative), it is also important to recognise the role of youth as the agents in initiating and driving such changes.

It was, however, not merely the inspirational leadership of well-known individuals, but, more importantly, a specific set of economic, institutional and demographic configurations that led to

1.In 2004, the Community Agency for Social Enquiry (CASE) identified Riverlea as one of their case studies in a study on the urban poor. The study was called, Voices of the poor: Case studies of urban poverty in the city of Johannesburg.

How to cite this article: Nel, R.W., 2014, 'Discerning the role of faith communities in responding to urban youth marginalisation', HTS Teologiese Studies/Theological Studies 70(3), Art. \#2743, 8 pages. http://dx.doi.org/10.4102/hts.v70i3.2743

Copyright: @ 2014. The Authors. Licensee: AOSIS OpenJournals. This work is licensed under the Creative Commons Attribution License. 
the activism of young people at this time. Hyslop (1990:7981) shows how under-resourced educational institutions struggled under the apartheid policies. He argues that these institutions, on the one hand, were not able to adequately handle the growth in the sheer numbers of, especially, African and Coloured students since the 1970s, amidst, on the other hand, a struggling economy that could not provide sustainable employment opportunities for these post-school youth (Hyslop 1990:82-85; cf. Chisholm 1992; Klouwerberg \& Butter 2011:58-59). These structural factors are confirmed by Terreblanche (2002:371-415), who shows the decline in the South African economy since 1974 and, parallel to this, the rise in structural unemployment in the period 1970-1995. Terreblanche notes (2002:374), ‘[u] nemployment is also higher among those younger than 25 years; in 1995 no fewer than $65 \%$ of Africans between the ages of 16-25 years were unemployed'.

This structural argument for understanding the genesis and development of youth activism was, however, not the only framework used in this discourse around the time of the first democratic elections in South Africa in 1994. From a different perspective, one can speak of a 'new struggle' against marginalisation.

\section{Youth in the struggle against marginalisation}

In the Second Carnegie Inquiry into Poverty and Development in Southern Africa, Wilson and Ramphele (1989:174ff.) identified (black) children to be among the most vulnerable in Southern Africa alongside women, the elderly and the disabled. They named three underlying causes of what they at the time called the 'wasting of young children': (1) absence of adequate income; (2) instability of family life due to the migrant labour system; and (3) absence of adequate preschool facilities in black communities (Wilson \& Ramphele 1989:175). Yet, while they reported on such structural realities, they also highlighted on a deeper level, what they called, 'the famine of the mind and of the spirit'. For them, this was even 'more serious' (Wilson \& Ramphele 1989:175) and surpassed the structural realities. They explained that:

Indeed, one might well argue that the spiritual destruction, though less visible than the bodily wasting of attrition, is even more damaging. Children are the most vulnerable victims of poverty in South African society and they must be the primary target group in any developmental strategy. (p. 176)

It seems that one can note a shift in the language and perspective on youth, from an emphasis on the structural realities to an emphasis on the deeper scars left by the 'struggle'. While these scholars (Chisholm 1992; Hyslop 1990; Wilson \& Ramphele 1989) still refer to the structural realities and as a result of that, the agency expressed in the activism of youth movements in the struggle against apartheid, they also raise the possibility that these efforts were futile and that the social costs outweighed the benefits. Wilson and Ramphele (1989) clearly show intimations of a new conversation and explain:
In the end stones were no match for whips and bullets; solitary confinement and terror could break practically any courage; student movements could not stand up against military organisation. Yet despite this vulnerability these young teenagers shook the country. The cost was nevertheless high ... (p. 176)

Their assessment of this high cost incurred for political activism by young people speaks of 'an almost irretrievable loss' (Wilson \& Ramphele 1989:177) and a (new) need for the 'development' of these young people. One can speak of a new struggle against marginalisation. In the subsequent literature we therefore see the shift towards this new language. Here, the youth are referred to as the 'lost generation' and 'marginalised' (Klouwerberg \& Butter 2011:59). Bray and her fellow authors, in particular, show how the literature on children and youth in South Africa shifted in emphasis from an almost exclusive, primary focus on participation in political activities of the 1980s and early 1990s (Bray et al. 2010; cf. Seekings 1996; Straker 1992; Ntsebeza 1993), that is, the structural, to a response to what some would deem a moral panic over a 'lost' or 'marginalised' generation (Everatt \& Orkin 1993; Van Zyl Slabbert et al. 1994). The former activism of the 'activists' and 'comrades' was now a threat: they were becoming a 'menace' to society, in particular to the much hailed political transition (Bray et al. 2010:28). The 'Youth' were now constructed not only as the objects of policy decisions, but also as the objects of criminal justice and social welfare programmes.

In line with this shift in emphasis in this social welfare framework, one could observe a new upsurge in media portrayals of youth 'gangs'. Chisholm (1992:4), in particular, points to a distinction emerging in this period, between what she categorises as: 'organised youth movements', 'unorganised youth' and 'urban youth gangs'. She explains:

The emergence in the 1980s of the 'comtsotsi', youth engaged in anti-social behaviour and who attempt to justify their behaviour as legitimate political activity points to a blurring of the lines between organised youth movements and gangs. In addition to the social, economic and political problems they face, youth organisations in the 1990s confront problems including inexperienced leadership; the rising of the comtsotsi phenomenon; an influx of new and undisciplined youth; as well as a generally confusing political terrain where on the ground nothing significant has changed and yet political violence is no longer openly condoned by the leadership of the movement. (p. 4)

Cross (1992:198) also argues that since the 1990s one can observe a fragmentation of the 'youth resistance culture' of the late 1980s, into a 'youth in reconstruction culture in diversity'. Consequently, the Reconstruction and Development Programme (RDP) of the African National Congress (ANC) and the policy-making phase, after the wellknown Joint Enrichment Project-Community Agency for Social Enquiry (CASE) study called, Growing up tough (Everatt \& Orkin 1993), conceptualised an 'asset-based approach', in which 'youth activism' became 'youth development'.

These reflections played a key role in adopting a new language and framework for understanding youth in the 'New South Africa'. Ramphele (2009:17) speaks of this (new) challenge as 
the 'spiritual destruction' and calls for action in the 'spiritual realm'. In this later reflection on the transformation that unfolded in the 1990s, Ramphele therefore calls for a deeper level of understanding the challenge. She states: 'Laying the ghosts to rest entails transcendence' (2009:17) According to her, the challenges of transformation were more than the 'material issues in the socio-economic and political domains' (2009:17). She continues, 'human beings as the main actors in history are framed in significant ways by spiritual and psychological impulses that go beyond material needs' (2009:17). This is action and a struggle against despair and marginalisation, but one would question Ramphele's almost exclusive emphasis on the personal and individual over against the structural. A more nuanced approach is therefore called for.

\section{Responding to urban youth marginalisation}

The question, then, is how we as scholars are to respond to youth marginalisation broadly, but also with specific reference to the author's own case study focus on the urban community of Riverlea. An interdisciplinary, postcolonial urban public theology would take their experiences and reflections, that is, their struggles against marginalisation, seriously. Importantly, therefore, one has to ask whether the current discourses within the disciplines of theology that traditionally have dealt with issues related to children and youth, namely, the discipline of practical theology and its related subfields of Christian education and youth ministry, have addressed all the contemporary struggles of youth sufficiently. The Youth at the Margins (YOMA) interdisciplinary research project, currently underway and involving scholars from South Africa and various Nordic countries, aims to address this shortcoming in greater depth (see Swart 2013).

For Swart (2013:6), the YOMA project builds on previous experiences in terms of method and approach, but is more focused on marginalised youth in society. He explains that:

[W]ithin a strongly supportive theoretical framework that recognizes that youth marginalisation and its related social problems are a phenomenon shared by societies in both the global South and global North, the new research undertaking will, on the basis of the existing literature, nevertheless proceed from an understanding that the South African youth context is an extreme case in point in comparison to the youth contexts of the Nordic partners. (p. 7)

Further, Swart (2013) notes:

It can thus be pointed out how, in the present South African youth context, there is a stark discrepancy between policy and strategically oriented documentation, which refer optimistically to a 'demographic dividend' (which holds that the country's youth bulge, i.e. almost half of the country's total population, has great potential to promote economic growth) and a small but growing corpus of critical scholarship emphasizing the ongoing failure of government and market forces to implement policy and create development opportunities, respectively, for the benefit of the country's youth. As a result, while there may be a 'demographic dividend', those with a critical perspective on the current South African youth context point out that there is no 'democratic dividend' for a very large section of the country's youth ... [T] hey remain rather statically 'stuck in the margins' - in the geographical sense, but also in terms of their personal physical deprivation, structural isolation and lack of opportunities for development and participation (economic, political and social) in the post-apartheid democratic system. (pp. 7-8)

In responding to this, the YOMA project aims to focus on the role that faith-based organisations play, and, more specifically, religious agency in relation to marginalised youth (Swart 2013:10). This will be done through seven carefully selected case studies, four from South Africa and three from Finland, Sweden and Norway, respectively. These cases will be the space where empirical research will be conducted. This will be done specifically through a qualitative approach, where individual semi-structured interviews and focus groups will be conducted on the basis of a list of predetermined themes as well as through an innovative methodology called participatory photography, as an additional data-gathering source (Swart 2013:22).

These processes are indeed crucial in starting to inform the key policy processes and draw from the important input by the disciplines of sociology and of youth and gender studies. In this contribution, I will, however, also introduce the notion of discernment and the relevance of this concept in relation to the praxis cycle as an appropriate methodology in urban theology, in order to deepen the theological engagement in the above-mentioned YOMA project. In what follows I present my model for dialogue towards social cohesion.

\section{Praxis cycle as discernment}

In my research (Nel 2013), I argued that the contribution of Madge Karecki has been helpful as a starting point for discernment in the way in which she explains the praxis-based expression of missiology (cf. Bevans \& Schroeder ([2004] 2009:348-395). Karecki shows how using her adoption of the 'pastoral circle' (Holland \& Henriot 1983), otherwise called the 'circle of praxis', could assist in healing 'the rift between theology and life' (Karecki 2005:159). A postcolonial urban theology, in taking seriously the struggles of youth against marginalisation, would have to stand within this particular tradition. This tradition was articulated by participants at the meeting of the Ecumenical Association of Third World Theologians (EATWOT) in 1976 who introduced their concept of an 'emergent gospel', stating that they were taking up the challenge of 'discernment' (Torres \& Fabella 1978:xii). For them, (as activist-theologians), this was to be done 'in obedience to the Spirit and in communion with the church' (Torres \& Fabella 1978:xii). Henriot ties this notion to what he calls 'the ordinariness of God's action in history' (Henriot 2005:38). Although we do not find this term 'discernment' explicitly in the Old Testament, it does find expression in the prophetic tradition, where God's voice is 'heard' by the individual prophet in terms of what is happening amongst and with the people of Israel throughout their history. This in turn implies that the calling of the prophetic theologian is to interpret or 'read' and 'see' the signals or impulses of God's action. In the light of this, the key question is: What 
then would be the particular methods, in addition to what YOMA already envisions, that should guide this particular process of discernment?

Karecki (2002:138-141) argues convincingly that appropriated as a missiological hermeneutical tool, the praxis cycle can offer a key starting point, but also the route and practical method in this process of discernment. This method enables students to do research (and therefore in her case, missiology), for the sake of transformation, rather than merely studying missiology. This is relevant for an urban public theology and the basis for much of the work done in the South African context. One, however, also has to follow the ongoing discourse on the various possibilities in which the pastoral cycle has been used and adopted (Cochrane et al. 1991; Kritzinger 2002, 2008; Wijsen et al. 2005), but more specifically, how Holland and Henriot themselves envisioned it. Taking into account the critique by Ward (2008), this cannot be a mechanical step-by-step process. Ward (2008:34f.) focuses on how it was introduced in practical theology. Ironically, by using only this exposition of the pastoral cycle, as 'a series of different stages through which the practitioner must move to implement the methodology' (Ward 2008:34), and not the now classic text of Holland and Henriot itself, or further appropriations thereof, Ward (2008:35) comes to the conclusion that ' $[t]$ he pastoral cycle tends to reinforce the dislocation between reflection and the everyday'). In agreement with Holland and Henriot, but also mindful of the intentions of Karecki and Ward, the praxis cycle is more than simply a method with a series of stages, or a recipe to be followed; it goes beyond the uncritical application of the techniques of the various social sciences.

Discernment in a scholarly context is about nurturing the craft for a conscious and critical picking up of 'impulses' (Saayman 2000:6) about what is happening in the world, in relation to the Divine. It happens, as Holland and Henriot ([1983] 1992:x) explain, 'continually grounded' in the actual praxis and interaction with all the participants, whilst listening and being open to God's impulses. The actual journey or pilgrimage of discernment is therefore much more intuitive and cyclical, grounded and often 'disturbed' by the actual praxis of the research participants - in the case of YOMA, the youth themselves. Guided as a central notion, discernment, therefore, allows for creative and imaginative 'innovation', depending on where we researchers find ourselves, the kind of questions that shape our engagement and the deeper levels of enlightenment that every new cycle calls for. All of this is, however, kept together, integrated in terms of the question: What is the Spirit of God searching, saying and doing? In this appropriation, then, I propose what Kritzinger (2002:150) calls the 'constant interplay - and a delicate correlation - between the various dimensions ...' This interplay is not only between the various dimensions of the praxis cycle, but also between researchers and their social realities, as well as researchers and the research participants. This implies a sensitive, but also creative dialogue, which adds to the discernment journey the reality and agency of the research participants as dialogue partners, interlocutors, and co-researchers. In the context of the YOMA project, this is a search for a sensitive and creative dialogue with the contemporary (postcolonial) cohort of younger generations, in particular those in urban communities, like Riverlea. Theologically this is underpinned by the openness to God's artistic creativity which is poured out and performed in all of creation, and Jesus' incarnation which affirmed this world as the arena of God's loving, outpouring of himself. Theology, here experienced and performed as art, allows this 'constant interplay' or creative dialogue and affirms the continuing presence and energy of the Holy Spirit, opening us (also as researchers) to an always deeper revelation of God's impulses.

Kritzinger (2002) shows how these notions of 'discerning' form the epistemological heart of a missiological methodology. Discernment, understood in this way, is also more than an objectified and clinical 'analysis' of the context or the social actors 'out there' in the quest for objective truth. Rather, this kind of research methodology is based on an inter-subjective epistemology which resonates with Sobrino's (2005) reflections on the three dimensions of human intellectual activity, namely to get a grip on reality by being truly and actively involved in reality; to 'take on the burden of reality' and take charge in transforming reality, but also to 'take responsibility' for reality. For him such activity means 'letting ourselves be enlightened by reality' (Sobrino 2005:10; emphasis added). Yet, in the same breath it remains important to take heed of the warnings of Bosch (1991) as he affirms that while the 'historical world situation' (or our local urban contexts like Riverlea) has to be 'incorporated as a constitutive element in our understanding of mission':

... this does not mean that God is to be identified with the historical
process ... [T] here is in Christianity a revolutionary and creative
strain which does not allow it to be reduced to a human, albeit
Christian, project. The 'new creation' Paul talks about irrupts not
so much because of Christian involvement in history; it comes
about through Christ's work of reconciliation (cf. 2 Cor 5:17), that
is, primarily through God's intervention. (p. 426)

With this kind of discernment in creative dialogue, through a particular methodology of the praxis cycle in mind, I now turn to the various shifts in youth movement research from our immediate South African context against the backdrop of my first section and, subsequently, will show the implications for a possible model for discerning the role of faith movements in responding to urban youth marginalisation.

\section{Shifts in studies on youth movements}

Since the 1960s various popular youth movements became the focus of study in South African theological scholarship (see bibliography Smith 1974). However, such studies were mostly undertaken with the aim to contain or control those movements, or with a view to 'saving' and condescendingly 'reaching out' to the 'lost' youth. It is in the light of this recognition together with the insights from the previous section on discernment that another response is crucially called for - a sensitive and creative dialogue, which goes beyond the mere description of 'symptoms' or an objectified social analysis that inevitably leads to an objectification of the younger generations upfront. 
In the first part of this article I indicated how youth movements have been understood since the 1990s and the changes that have occurred since then. I indicated that a shift occurred towards a stronger focus on youth in a struggle against marginalisation. Having said this, one can at this point also observe how, since the 1994 elections, the struggle tradition itself has continued in the form of new protest movements against various government and institutional policies (Bond 2004:10-11; Pillay 2003:283-313). Related to the media depictions of the 'lost generation', one could refer to organisations like the Western Cape Anti-Crime Forum (WCACF), People Against Gangsterism and Drugs (PAGAD), as well as the Treatment Action Campaign (TAC), Landless People's Movement and Anti-Privatisation Forum $(\mathrm{APF})$, with various new religious alliances and what some would call right-wing formations linked to some of these organisations. It is therefore important, in the light of these new forms of activism and agency, to recalibrate our tools of enquiry, as one cannot simply lump all of these movements together (Bond 2004:23-27).

Therefore, in the next section I continue an exploration for sharper tools of enquiry in an effort to understand the emerging reality of the new struggles against marginalisation. For youth researchers what is needed is a review of the tools of enquiry, in the light of, what Badsha (2003:131) calls, 'reworking our understanding of South African culture and identity, both under apartheid as well as its more contemporary shapes' (emphasis added). Badsha (2003:132) shows in both the popular and academic imagination that the post-apartheid South African society is a radically different place; yet she argues convincingly that one cannot completely discard categories of race and resistance 'in trying to make sense of the new'. She argues that the lenses related to a specific set of political and economic policies before 1994, that is, the structural, and the welfare framework remain important, but are not the only ones adequate anymore. In using the title, 'Old skool rules/new skool breaks', Badsha (2003:132) shows how through the contestations within a particular expression of youth culture such as the Hip-Hop, 'the past and the present are in constant negotiation and that it is within this negotiation that many of the most exciting and creative innovations often occur'.

I would argue that Badsha's emphasis on the 'constant negotiation' and 'creative innovations' between the old and the new is a deeper engagement of the struggles of youth, in a new context of transformation. Badsha (2003:133) speaks here, self-consciously, from the heart of youth culture, of what she calls, 'change and innovation' that 'forces one to think in more complex terms than a simplistic black/ white contrast and to read the rich layers of meaning from seemingly simple, but always complex interactions and performances'. Through a local case study of what she calls, 'a moment of spontaneous performance' that she witnessed between members of the TVA6 graffiti crew, she shows how complex interactions take place, where:

... youth identities are not created by breaks with the old and then suddenly new ones appear instantly. They instead overlap and are negotiated constantly, both in a spirit of playfulness and sometimes of conflict, making it difficult to make strict or clear divisions between old and new skool. (Bashda 2003:135)

She places this discourse between the old and the new within the framework of the kind of 'changes that the South African youth culture has had to adapt to since the early 1990s' (Badsha 2003:135) and the transformations 'facilitated by the breaking down of the apartheid legislation and the way this has ... facilitated the ending of the isolation that was imposed on South Africa by the international community' (Badsha 2003:136). For her:

Rather than it being about a break between the old and the new, it is about having to renegotiate identities in the context of much more rapid change and easier flow of information and meanings ... Before 1990, youth culture was constrained by the limitations imposed on it by the apartheid state, and it was much harder for youth to plug into the global youth scene and the commodities of youth culture were much harder to procure ... As South Africa opened its borders and trade sanctions were lifted, the commodities of youth culture became more accessible to more people. Seemingly overnight South African youth had far greater and easier access to information and influences from international youth culture. (p. 136)

Naidoo (2009:153-168) also affirms this renegotiation of identities that Badsha refers to and also places it explicitly within the broader (global) framework. As indicated earlier, Naidoo was deeply involved in student movements in the 1990s. She argues that a 'neoliberal world economy and political arena' (Naidoo 2009:154), driven by the values of a 'neo-liberal macroeconomic framework' (Naidoo 2009:162), has impacted directly on the continued reproduction of social inequalities, also of youth. This has induced a silencing of the youth and student movements. She states from the context of student movements:

Armed with a vision of a transformed higher education system and society, the student movement offered some space for the intellectual pursuit of alternatives to capitalism and neoliberalism and for the production of graduates and leaders who would not merely accept and entrench the logic of neoliberalism. Sadly, however, this potential was to be closed as the duty to govern taken by the ANC demanded the production of academics and policy-makers who would not question but rather facilitate the entry of neoliberalism into the country. (p. 159)

This demand for 'duty to govern' academics and policymakers that Naidoo refers to, has been a feature also of theological developments since the 1990s and it is therefore important to engage the questioning of the entry of neoliberalism. It is in this context then that the argument from social scientists like Larana, Johnston and Gusfield (1994) and Tarrow (1998), for a new paradigm in understanding (social) movements, against neo-liberal globalisation, becomes relevant for the dialogue and understanding of youth movements. As a missiologist, Leffel's (2007:45) appropriation of these insights is helpful and in my view resonates with the kind of methodology that I envisage.

Leffel shows how youth movements played key roles in the social uprisings as symbolised by the 'revolution of 1968', not only in attempting to change society, but also in changing the forms and dynamics of social activism. He continues that since then some social scientists of social movements 
(Larana et al. 1994; Melucci 1996) started to speak of new social movements (NSMs) that go beyond classic, class-based social movements, as defined by sociologists of a Marxist orientation (Leffel 2007:46, 52f.). For Larana et al. (1994:loc. 19), this is 'a provocative and innovative reconceptualization of the meaning of social movements'). Leffel (2007:46) on his part, refers to the helpful typology of Ray and Anderson (2000), which divides NSMs into political movements, consciousness movements and 'cultural arms' that challenge cultural ideas. This work of NSM researchers is relevant for missiology and, I would suggest, for an urban public theology, as it goes deeper than merely playing a role in understanding transformation as institutional restructuring or personnel change. This work also delves into the shifting of the deeper values of society. Further, it makes the crucial link between the agency of the individual actor, the means and the outcome of the NSMs as 'purposive collective actions'. Larana et al. (1994:loc. 43) show that embedded in the 'student movements of the 1960s', was already the seed that 'heralded the first challenges' to the classic paradigms of interpreting social movements (Larana et al. 1994:loc. 52; Leffel 2007:4546). The classic paradigms in studying social movements focused on 'theories of ideology', that is, the structural argument and later 'theories of organisation' (Larana et al. 1994:loc. 20). Yet, in the focus on NSMs one observes a shift towards what Badsha proposes as a deeper reading of the rich layers of negotiations. Here a cultural framework emerges, where the innovative creation of meaning and identity comes to the fore, as well as the design of alternative spaces for living out the emerging cultures. The repressive and outdated forms of sense-making, but also of resistance, are reimagined in terms of the limitations and opportunities that are not defined, primarily, in terms of ideological, structural and class realities. The upsurge in a focus on local issues, for example in an urban community like Riverlea, relates now to strategy and organisation, but also to collective identity against the globalising logic of sameness and ideological loyalty. These notions have become critical in the study of youth movements.

\section{Constructing a methodology for a postcolonial urban theology}

In the disciplines of practical theology, systematic theology, youth ministry and even urban missiology, at least in Southern Africa, there remains a lack of a deeper and broader framework for understanding the newer expressions of youth and student movements in the post-colonial context. Despite the key role that youth movements have played in the ecumenical movement and in the transformation of societies, still, within urban communities such as Riverlea this is not a key issue in theology. There continues to be a plethora of research output on the anti-colonial liberation theologies, now known as public theologies, which seems to fit into Naidoo's scheme, as 'duty-to-govern' academics. In this respect, as envisioned by the urban public theology initiative and YOMA, the actions and reflections from youth themselves, from the perspective of the various NSMs inducing social transformation, provide an important alternative, as a deepening and broadening of our methodology.
In this article, I have shown the deeper dynamics of the shifts within the phenomenon of youth activism and youth research. This assessment opens the way for an appreciation of the agencies of new producers of youth movement culture: the youth themselves as creative dialogue partners. The journeys of these youth in a new social context, and therefore not only their struggles but also their 'creative innovations', are critical for a deeper understanding of the current ongoing struggles of faith-based organisations against the problem of youth marginalisation. In line with a postcolonial framework, then, what is suggested is an interpretation where the traditional binaries of oppressed versus oppressor, white versus black, rich versus poor, et cetera, are transcended towards 'a quest for a new humanity', or social cohesion as the antidote to marginalisation. The local struggles, often as struggles for identity, are connected with global networks, reimagining identity and social spaces. These multi-vocal innovations, sometimes perceived as being 'lost' in 'ill-discipline' or 'rebellion', within faith communities, due to the lack of a more sophisticated set of tools to read and understand the complex innovations, led to a 'rhetoric of despair' in the face of a perceived lack of youth participation and activism.

At an earlier section, I identified the missiological praxis cycle as the starting point for a deeper discerning of the role of faith communities. In doing so, I affirmed the critical importance of the creative dialectical movement and interplay between insertion, social analysis, theological reflection and action plans. Yet, this broadening and deepening suggested another dimension to the missiological praxis cycle. This dimension, in line with NSM's research discussed in the latter part of this article, points to the importance of local struggles, and therefore notions of agency of the individual actor, the means and the outcome, in other words, the participant biography, opportunity structure and rhetorical framing of their world, which lead to an outcome, namely, the movement culture and concrete protest strategies. These components are not in a particular order and I argue, in line with the missiological praxis cycle, for the necessity of a multi-dimensional matrix to understand youth, incorporating these components in the existing missiological praxis cycle. Schematically such an integrated matrix might look like the example in Figure 1.

The dimensions of the missiological praxis cycle can be seen in this diagram (white), as well as the dimensions from an NSM perspective (blue). This matrix depicts a deepening of the praxis cycle to also take into account the struggles and creative negotiations and innovations from youth as expressions of NSMs. In this art of discernment, one can trace the basic structure from the genius of the praxis cycle, yet, also the new moves, and improvisations in a postcolonial context. This is a shift from a framework towards an interactive matrix, where different dimensions interact. In all of this, one can detect a 'go-between', connecting spirituality, instead of disruption, and thus, this creative interaction becomes an indication of a new agency towards social cohesion towards hope. 


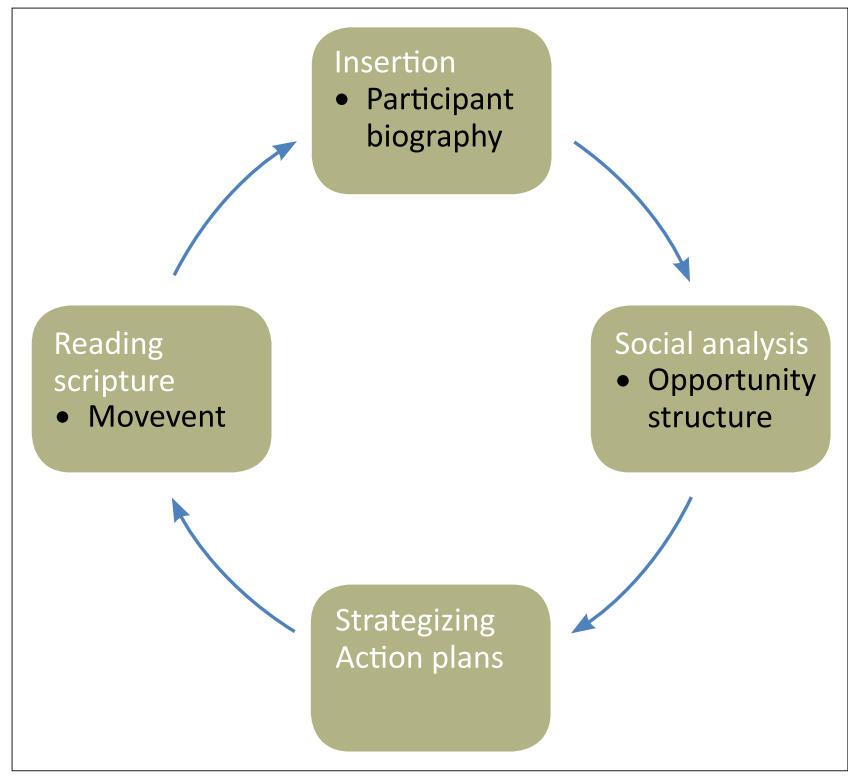

FIGURE 1: A postcolonial matrix to understand youth.

\section{Conclusion}

In responding to urban youth marginalisation that is often expressed as violence or tension within communities, one can also see a moment of opportunity for building a creative dialogue towards social cohesion. This dialogue not merely affirms the youth as research partners, but also, in a broader matrix of urban public theology, as co-creators. This means that a community like Riverlea brims with possibility and hope, in the context of the envisioned YOMA initiative.

\section{Acknowledgements}

This work is based on the research supported by the National Research Foundation (NRF) and College of Human Sciences (CHS), University of South Africa. Any opinion, finding and conclusion or recommendation expressed in this material is that of the author. The NRF and CHS do not accept any liability in this regard.

\section{Competing interests}

The author declares that he has no financial or personal relationship(s) which may have inappropriately influenced him in writing this article.

\section{References}

Badsha, F., 2003, 'Old skool rules/new skool breaks: Negotiating identities in the Cape Town Hip-Hop scene', in H. Wasserman \& S. Jacobs (eds), Shifting selves: Postapartheid essays on mass media, culture and identity, pp. 131-143, Kwela Books, apartheid
Cape Town.

Bevans, S.B. \& Schroeder, R.P., 2009, Constants in context: A theology of mission for today, Orbis, Maryknoll, NY.

Bond, P., 2004, Talk left, walk right: South Africa's frustrated global reforms, University of KwaZulu-Natal Press, Pietermaritzburg.

Bosch, D.J. 1991, Transforming mission: Paradigm shifts in theology of mission, Orbis, Maryknoll, NY.

Bray, R., Gooskens, I., Kahn, L., Moses, S. \& Seekings, J., 2010, Growing up in the new South Africa: Childhood and adolescence in post-Apartheid Cape Town, HSRC Press, Cape Town.

Chisholm, L., 1992, 'State policy and youth unemployment in South Africa, 19761992', paper presented to the Economics of Education Association Conference, University of Cape Town, Cape Town, 04-05 September.
Cochrane, J.R., De Gruchy, J.W. \& Petersen, R., 1991, In word and deed: Towards a practical theology for social transformation, Cluster Publications, Pietermaritzburg.

Community Agency for Social Enquiry (CASE), 2004, Voices of the poor: Case studies of urban poverty in the city of Johannesburg, viewed 27 October 2013, from http://www.joburg-archive.co.za/corporate_planning/Case.pdf

Cross, M., 1992, Resistance and transformation: Education, culture and reconstruction in South Africa, Skotaville, Johannesburg.

Everatt, D. \& Sisulu, E. (eds.), 1992, Black youth in crisis: Facing the future, Ravan, Johannesburg.

Everatt, D. \& Orkin, M., 1993, Growing up tough: A national survey of South African youth, Community Agency for Social Enquiry, Johannesburg.

Freire, P., 1993, Pedagogy of the oppressed, Penguin Books, London.

Ganzevoort, R., 2009, 'Forks in the road when tracing the sacred: Practical theology as hermeneutics of the lived religion', Presidential address to the 9th conference of the International Academy of Practical Theology, Chicago, United States of America, 03 August, viewed 12 July 2012, from http://www.ruardganzevoort.nl/ America, 03 August, viewed
pdf/2009_Presidential.pdf

Henriot, P., 2005, 'Social discernment and the Pastoral cycle', in F. Wijsen, P. Henriot \& R. Meijsa (eds.), The pastoral circle revisted. A critical quest for trust and transformation, pp.15-26, Pauline Publications, Nairobi.

Hlongwane, K.A., Ndlovu, S. \& Mutloatse, M., 2006, Soweto '76: Reflections on the liberation struggles, Mutloatse Arts Heritage Trust, Houghton.

Holland, J. \& Henriot, P., [1983] 1992, Social analysis: Linking faith and justice, 9th Printing, Orbis, Maryknoll, NY.

Hyslop, J., 1990, 'Schools, unemployment and youth: Origins and significance of student and youth movements, 1976-1987', in B. Nasson \& J. Samuel, Education From poverty to liberty, pp. 79-87, David Phillip, Cape Town.

Karecki, M. (ed), 2002, The making of an African person: Essays in honour of Willem Saayman, Daan Roux Printers, Pretoria.

Karecki, M., 2005, 'Teaching missiology in context: Adaptations of the pastoral circle', in F. Wijsen, P. Henriot \& R. Meijsa (eds.), The pastoral circle revisited: A critical quest for truth and transformation, pp. 159-173, Pauline Publications, Nairobi.

Keifert, P. (ed.), 2009, Testing the spirits: How theology informs the study of congregations, Eerdmans, Grand Rapids, MI.

Klouwerberg, F.K. \& Butter, I., 2011, 'African “Youth" since Independence: Notes on a bibliographic overview, 1990-2005', Africa Development 35 (3/4), 55-66.

Melucci, A., 1996, Challenging codes: Collective action in the information age, Cambridge University Press, Cambridge.

Kritzinger, J.N.J., 2002, 'A question of mission - A mission of questions', in M. Karecki (ed.), The making of an African person: Essays in honour of Willem Saayman, pp. 144-173, Daan Roux Printers, Pretoria.

Kritzinger, J.N.J., 2007, 'Nurturing missional integrity', unpublished paper presented at Departmental seminar, Unisa, Pretoria.

Kritzinger, J.N.J., 2008, 'Faith to faith: Missiology as encounterology', Verbum et Ecclesia 29(3), 764-790. http://dx.doi.org/10.4102/ve.v29i3.31

Larana, E., Johnston, H. \& Gusfield, J.R., 1994, New social movements: From ideology to identity, Temple University Press, Philadelphia, PA. (Kindle edn.)

Leffel, G., 2007, Faith seeking action: Mission, social movements, and the church in motion, Scarecrow Press, Lanham, MD.

Naidoo, P., 2009, 'Taming the young lions: the intellectual role of youth and student movements after 1994', in W. Gumede \& L. Dikeni (eds.), The poverty of ideas: South African democracy and the retreat of intellectuals, pp. 153-168, Jacana, South African dem
Auckland Park.

Nasson, B. \& Samuel, J., 1990, Education: From poverty to liberty, David Phillip, Cape Town.

Nel, R.W., 2013, 'Discerning an African missional ecclesiology in dialogue with two uniting youth movements', DTh thesis, University of South Africa.

Ntsebeza, L., 1993, 'Youth in urban African townships, 1945-1992: A case study of the East London townships', MA dissertation, University of Natal.

Pillay, S., 2003, 'Experts, terrorists, gangsters: problematising public discourse on a post-apartheid showdown', in H. Wasserman \& S. Jacobs (eds), Shifting selves: Postapartheid essays on media, culture and identity, pp. 283-313, Kwela, Cape Town

Philipps, J., 2014, 'Dealing with diversity: African youth research and the potential of comparative approaches', Journal of Youth Studies, viewed 25 June 2014, from http://dx.doi.org/10.1080/13676261.2014.918252

Ramphele, M., 2009, Laying ghosts to rest: Dilemmas of the transformation in South Africa, Tafelberg, Cape Town.

Ray, P.H. \& Anderson, S.R., 2000, The cultural creatives: How 50 million people are changing the world, Three Rivers Press/Random House, New York.

Root, A. \& Dean, K., 2011, The theological turn in Youth Ministry, IVP Books, Downers Grove, IL. (Kindle edn.)

Saayman, W., 2000, 'Missionary by its very nature ...' A time to take stock', Missionalia 28(1), 4-22.

Seekings, J., 1996, 'The "Lost Generation": South Africa's "youth problem" in the early-1990's', Transformation 29, 103-125.

Segundo, J.L., [1976] 1992, The liberation of theology, Orbis, Maryknoll, NY.

Smit, A., 2001, Meetings that matter: Leadership, spirituality and discernment in congregations, Lux Verbi, Wellington. 
Smith, M.D.J., 1974, 'Die Jesus People - Beweging: 'n Kritiese beoordeling', MTh verhandeling, Stellenbosch Universiteit.

Sobrino, J., 2005, 'Faith, justice, and injustice', in F. Wijsen, P. Henriot \& R. Meijsa (eds.), The pastoral circle revisited: A critical quest for truth and transformation pp. 9-17, Pauline Publications, Nairobi.

Soudien, C., 2007, Youth identity in contemporary South Africa: Race, culture and schooling, New Africa Books, Claremont.

Straker, G., 1992, Faces in the revolution: The psychological effects of violence on township children in South Africa, David Phillip, Cape Town.

Swart, I., 2013, 'Youth at the margins: Introducing a new research initiative in an ongoing south-north collaboration in the context of international diaconia' Diakonia 4(1), 2-26

Tarrow, S., 1998, Power in movement: Social movements and contentious politics, Cambridge University Press, Cambridge. http://dx.doi.org/10.1017/ CBO9780511813245

Tau, S., 2009, 'Riverlea residents to disrupt World Cup', The Citizen, 10 October, viewed 27 October 2013, from http://ccs.ukzn.ac.za/default.asp?3,28,10,3524

Terreblanche, S., 2002, A history of inequality in South Africa 1652-2002, University of KwaZulu-Natal Press, Pietermaritzburg.
Torres, S. \& Fabella, V., 1978, The emergent gospel: Theology from the developing world, Goeffrey Chapman, London.

Van Dijk, R., De Bruijn, M., Cardoso, C. \& Butter I., 2011, 'Introduction: Ideologies of youth', Africa Development 35(3/4), 1-17.

Van Zyl Slabbert, F., Malan, C., Marais, H., Olivier, J. \& Riordan, R., 1994, Youth in the New South Africa, HSRC, Pretoria.

Ward, P., 2008, Participation and mediation: A practical theology for the liquid church, SCM Press, London.

White, D., 2005, Practicing discernment with youth: a transformative youth ministry approach, Pilgrim Press, Cleveland, $\mathrm{OH}$.

Wijsen, F., 2005, 'The practical-theological spiral: Bridging theology in the West and the rest of the world', in F. Wijsen, P. Henriot \& R. Meijsa (eds.), The pastoral circle revisited: A critical quest for truth and transformation, pp. 129-147, Pauline Publications, Nairobi.

Wilson, F. \& Ramphele, M., 1989, Uprooting, poverty: The South African challenge, David Phillips, Cape Town.

Wyn, J. \& White, R., 1997, Rethinking youth, Sage, London. 